\title{
Mengatasi Perilaku Membolos Peserta Didik Menggunakan Konseling Individual
}

\section{Busmayaril, Efi Umairoh}

\author{
Universitas Islam Negeri Raden Intan Lampung \\ busmayaril@radenintan.ac.id
}

Submitted: 20-04-2018, Revised: 06-06-2018, Accepted: 20-06-2018

\begin{abstract}
Counseling service activities can be organized either individually or in groups. Individual counseling services are conducted through individual counseling, while group by group counseling. Individual counseling is directed to learners to help correct inadequate habits / deviant behavior (truancy behavior) in order to become better behaviors in the school environment. The results of pre-research surveys that the authors obtain in Senior High School (SMA) Pangudi Luhur Bandar Lampung indicate that there are still learners who do pelanaggaran school rules (ditching). The method used in this research is field research (field research) with the type of descriptive research. The population in this study were students of class XI and 1 counseling teacher, from the total of students of class XI, the writer took 7 students plus 1 teacher guidance and counseling to be sampled in this research. Data collection techniques used interview, observation and documentation method, while to analyze data used qualitative data analysis method using inductive and deductive thinking approach. Based on the processing and analysis of data that the authors do in this thesis is known that the implementation of individual counseling services occur mostly based on BK teacher initiative is by calling learners, other than that the condition of facilities and infrastructure are inadequate to conduct individual counseling. Therefore, BK teachers should master the knowledge of the field of technical counseling and the steps that will be implemented, so that the implementation of individual guidance and counseling services in the school goes well and maximally.
\end{abstract}

Keywords: Skipping; Counseling; Individual

\begin{abstract}
Abstrak: Kegiatan layanan konseling dapat diselenggarakan baik secara perorangan maupun kelompok. Secara perorangan layanan konseling dilaksanakan melalui konseling individual, sedangkan secara kelompok melalui konseling kelompok. Konseling individual ditujukan kepada peserta didik untuk membantu memperbaiki kebiasaan yang kurang memadai/perilaku menyimpang (perilaku membolos) agar menjadi perilaku yang lebih baik lagi di lingkungan sekolah. Hasil survey pra penelitian yang penulis peroleh di Sekolah Menengah Atas (SMA) Pangudi Luhur Bandar Lampung menunjukkan bahwa masih terdapat peserta didik yang melakukan pelanaggaran tata tertib sekolah (membolos). Metode yang digunakan dalam penelitian ini yaitu penelitian lapangan (field research) dengan jenis penelitian deskriptif. Populasi dalam penelitian ini yaitu peserta didik kelas $\mathrm{XI}$ dan 1 guru bimbingan konseling, dari jumlah keseluruhan peserta didik kelas XI, penulis mengambil 7 peserta didik ditambah 1 guru bimbingan dan konseling untuk dijadikan sampel dalam penelitian ini. Teknik pengumpulan data menggunakan metode interview, observasi dan dokumentasi, sedangkan untuk menganalisis data digunakan metode analisis data yang bersifat kualitatif dengan menggunakan pendekatan berfikir induktif dan deduktif. Berdasarkan pengolahan dan analisis data yang penulis lakukan dalam skripsi ini diketahui bahwa pelaksanaan layanan konseling individual terjadi kebanyakan didasari atas inisiatif guru BK yaitu dengan cara memanggil peserta didik, selain itu kondisi sarana dan prasarana yang kurang memadai untuk melakukan konseling individual. Oleh karena itu guru BK harus menguasai pengetahuan bidang konseling teknik dan langkah-langkah yang akan dilaksanakan, sehingga pelaksanaan layanan bimbingan dan konseling individual di sekolah berjalan dengan baik dan maksimal.
\end{abstract}

Kata Kunci : Membolos; Konseling; Individual

(C) 2018 KONSELI: Jurnal Bimbingan dan Konseling (E-Journal)

\section{Pendahuluan}

Sekolah adalah salah satu tempat untuk menyelenggarakan pendidikan formal yang memiliki peranan sangat penting dalam mewujudkan tujuan pendidikan. Pendidikan dapat menjadi bagian terpenting bagi masyarakat untuk menghantarkan setiap individu pada target 
tertentu sekaligus menyempurnakan peran individu sebagai makhluk yang paling mulia dan sangat mempengaruhi kehidupan manusia. konseling memiliki beberapa pengertian yaitu nasehat, anjuran, dan pembicaraan (Abu \& Uhbaiti, 2001).

Guru BK dapat malah satu layanan konseling yang dapatyaitu dengan layanan konseling individual. Konseling individual dapat memiliki makna yang spesifik dalam pengertian pertemuan konselor dengan konseli secara individual, dan terjadi hubungan konseling yang bernuansa hubungan, dan konselor dapat berupaya memberikan bantuan dalam mengembangkan pribadi konseli, sehingga konseli mampu mengatasi masalah-masalahnya(S. Willis, 2013).

Salah satu layanan konseling yang dapat dilakukan oleh guru BK adalah layanan konseling individual. Konseling individual mempunyai makna spesifik dalam arti pertemuan konselor dengan konseli secara individual, dimana terjadi hubungan konseling yang bernuansa rapport, dan konselor berupaya memberikan bantuan untuk pengembangan pribadi konseli serta konseli dapat mengatasi masalah-masalah yang dihadapinnya(S. Willis, 2013).

Dalam bimbingan konseling terdapat berbagai macam yang dapat digunakan untuk membantu mengatasi masalah yang dialami oleh peserta didik. Salah satu layanan konseling itu adalah layanan konseling individual atau yang sering juga dikenal dengan konseling nondirektif. Carl R. Rogers dipandang sebagai pelopor dan tokoh konseling tersebut. Menurut Rogers konseling dan psikoterapi tidak mempunyai perbedaan. Konseling yang berkembang pesat di Amerika Serikat dan diterima sebagai konsep, dan alat baru dalam terapi yang diterapkan tidak hanya bagi orang dewasa akan tetapi juga bagi remaja dan anak-anak(RichardJones, 2011).

Layanan konseling individual adalah layanan bimbingan dan konseling yang memungkinkan peserta didik yang mendapatkan layanan langsung secara tatap muka dengan guru pembimbing/konselor dalam rangka pembahasan dan pengentasan permasalahannya(Sukardi, 2000). Menurut Dewa Ketut Sukardi konseling individual atau yang sering disebut konseling non-directive, yaitu yang memberikan suatu gambaran bahwa proses konseling yang menjadi pusatnya adalah konseli, dan bukan konselor. Karena itu dalam proses konseling ini kegiatan sebagian besar diletakkan dipundak konseli itu sendiri. Dalam pemecahan masalah, maka konseli itu sendiri didorong oleh konselor untuk mencari serta menemukan cara yang baik dalam pemecahan masalahnya(Sukardi, 2000).

Proses layanan konseling individu di sini menekankan/berpusat pada konseli (melibatkan konseli) untuk memecahkan dan menyelesaikan masalah pribadinya secara optimal, bukan konselor yang memutuskan menyelesaikan masalah konseli tetapi konselor hanya memberi alternatif pemecahan masalahnya yang dihadapi konselinya. Individu konseli yang setaraf dengan individu konselor, sehingga dapat dihindari kesan bahwa konseli yang menggantung diri pada konselor dalam memutuskan menyelesaikan masalahnya sendiri. Berdasarkan beberapa pendapat di atas, maka dapat penulis simpulkan bahwa konseling individual adalah suatu metode perawatan psikis yang dilakukan dengan cara berdialog antara konselor dengan konseli, untuk menentukan isu yang penting bagi dirinya dan pada pemecahan masalah bagi dirinya, maka konseli itu sendiri didorong oleh konselor untuk mencari serta menemukan cara yang baik dalam pemecahan masalahnya. Konsep konseling individual ditujukan untuk membantu peserta didik memperbaiki kebiasaan yang kurang memadai (perilaku menyimpang) agar menjadi perilaku yang lebih baik terutama dilingkungan sekolah. Cara yang dilakukan yaitu dengan menyadarkan peserta didik atas sikap dan perilaku yang kurang tepat agar dapat diubah dan diperbaiki. Diharapkan peserta didik dapat memahami dan menyadari bahwa sikap dan perilaku lamanya itu tidak layak dilakukan dan mesti diubah menuju kondisi yang lebih baik dan tepat.

Perilaku peserta didik dalam kenyataan di lingkungan sekolah dapat dilihat dari tata tertib yang dibuat oleh lembaga pendidikan, pada prisipnya merupakan peraturan yang harus 36

https://ejournal.radenintan.ac.id/index.php/konseli

DOI: http://dx.doi.org/10.24042/kons.v5i1.2659 
dipatuhi oleh peserta didik. Untuk lebih jelas mengenai peraturan di SMA Pangudi Luhur Bandar Lampung sebagaimana dalam tabel berikut:

Peraturan Tata Tertib SMA Pangudi Luhur Bandar Lampung, yaitu:

1. Peserta didik diwajibkan berada dilingkungan sekolah 10 menit sebelum KBM dimulai

2. Peserta didik diwajibkan hadir selama satu semester $90 \%$ dari hari efektif

3. sekolah, apabila tidak terpenuhi maka dinyatakan tidak memenuhi syarat untuk penentuan kenaikan kelas

4. Peserta didik diwajibkan bertindak tertib dan teratur ketika memasuki atau meninggalkan ruang kelas

5. Peserta didik diwajibkan mengenakan seragam sekolah sesuai dengan ketentuan yang ada

6. Peserta didik diwajibkan memakai tanda lokasi, bet, dan tanda program keahlian yang ditempel pada kemeja

7. Peserta didik diwajibkan mengikuti upacara bendera setiap hari senin dan upacara hari-hari besar nasional

8. Peserta didik diwajibkan menjunjung tinggi nama baik diri sendiri, sekolah, masyarakat dan bangsa

9. Peserta didik diwajibkan menyampaikan secara lisan atau tertulis jika siswa berhalangan hadir

10. Peserta didik diwajibkan menjaga dan menciptakan kebersihan dan keindahan lingkungan sekolah

11. Peserta didik diwajibkan menyelesaikan tugas yang diberikan oleh guru dengan penuh tanggung jawab

12. Peserta didik diwajibkan menjunjung tinggi kultur dan adat budaya

13. Peserta didik diwajibkan mengikuti salah satu dari kegiatan pengembangan diri/ekstrakurikuler

14. Peserta didik dilarang membawa senjata tajam ataupun senjata lain yang tidak berkaitan dengan pelajaran

15. Peserta didik dilarang berjudi atau hal-hal lain yang bisa mengindikasikan perjudian

16. Peserta didik dilarang membawa buku bacaan/kaset atau HP yang memuat vidio pornografi

17. Peserta didik dilarang terlibat dalam tindakan perkelahian antara sesama siswa SMA Pengudi Luhur maupun siswa lain diluar SMA Pangudi Luhur

18. Peserta didik bagi laki-laki dilarang berambut gondrong, celana gembyong, celana berujung pensil, dan bertato

19. Peserta didik dilarang berkuku panjang, berandrok pendek, bermake-up, dan memakai perhiasan yang berlebihan

20. Peserta didik dilarang mengaktifkan handphone pada saat KBM berlangsung

21. Peserta didik dilarang membawa, mendistribusikan, dan mengkonsumsi miras, serta menyalahgunakan obat-obatan terlarang

22. Peserta didik dilarang merokok selama masih mengenakan seragam sekolah baik di sekolah maupun diluar sekolah

23. Peserta didik dilarang meninggalkan kelas atau jam pelajaran tanpa seizin guru

24. Peserta didik dilarang merusak sarana/prasarana yang ada di sekolah

25. Peserta didik dilarang mengambil barang-barang baik milik sekolah maupun milik teman yang bukan miliknya

26. Peserta didik dilarang memalsukan dokumen administrasi sekolah 
Peraturan di atas dapat digunakan sebagai bahan perbandingan untuk menilai perilaku peserta didik di sekolah, jika peserta didik mematuhi peraturan tersebut maka perilakunya baik, sebaliknya jika peserta didik melanggar peraturan tersebut berarti peserta didik menunjukkan perilaku yang kurang baik (perilaku menyimpang). Diharapkan peserta didik dapat mematuhi peraturan yang diterapkan oleh pihak sekolah, apabila peserta didik melanggar maka akan dikenakan sanksi yang merupakan tindakan yang diambil oleh pimpinan sekolah.

Masalah sosial dewasa ini yang terjadi di masyarakat cukup menjadi perhatian semua pihak, diantaranya adalah masalah kenakalan peserta didik. Adapun kenakalan peserta didik yang merupakan salah satu perilaku yang menyimpang. Sarlito Wirawan Sarwono mengatakan "kenakalan anak adalah tindakan seorang yang belum dewasa yang sengaja melanggar hukum dan yang diketahui oleh anak-anak itu sendiri bahwa jika perbuatan itu sempat diketahui petugas hukum ia bisa dikenai hukuman(Sarwono, 2010).

Kenakalan peserta didik dapat berawal dari lingkungan yang kurang kondusif bagi perkembangan peserta didik, baik lingkungan sekolah maupun lingkungan masyarakat sekitar. Selain itu, kepribadian kurang baik juga dapat menyebabkan kenakalan peserta didik, hal ini disebabkan karena kepribadian kurang baik itu pada akhirnya memicu timbulnya berbagai penyimpangan perilaku dan perbuatanperbuatan negatif yang melanggar aturan dan norma yang ada, baik lingkungan sekolah maupun masyarakat. Berkenaan dengan kenakalan remaja, adapun beberapa jenis atau bentuk kenakalan remaja yang ada di sekolah misalnya peserta didik yang tidak mengikuti pelajaran, membolos, merokok dilingkungan sekolah, datang terlambat, tidak memakai atribut, peseta didik yang suka membuka gambar atau situs porno, peserta didik menggunakan pakaian yang tidak sesuai aturan, dan lain sebagainya. Jensen sebagaimana yang telah dikutip oleh Sarlito Wirawan Sarwono membagi kenakalan peserta didik menjadi empat jenis, namun kenakalan yang sering ada di sekolah yaitu kenakalan yang melawan status, seperti merokok, pelajar sering membolos, sebagai anak melawan orang tua, membantah perintah orang tua dan lainnya(Sarwono, 2010).16

Kaitannya dengan masalah remaja di sekolah, kenakalan remaja yang sangat marak diperbincangkan adalah masalah membolos. Perilaku membolos bukanlah hal yang baru lagi bagi kalangan pelajar. Menurut Bachri Thalib, akibat dari perilaku menyimpang khususnya membolos tersebut dapat berdampak bagi diri sendiri dan orang lain, diantaranya ketidakmampuan berprestasi, peserta didik menggunakan waktu luangnya untuk mengganggu temannya di kelas, kegelisahan yang tidak realistis, kesedihan dan depresi, kesulitan bergaul dan ketergantungan yang berlebihan kepada guru(Thalib, 2010).

Kata "bolos" sangat populer dikalangan pelajar atau peserta didik baik di sekolah tingkat menengah atau tingkat atas. Dari beberapa survei, jumlah peserta didik yang membolos pada jam efektif sekolah hanya sedikit dibandingkan dari jumlah peserta didik yang tidak membolos, terlepas sekecil apapun dari jumlah tersebut harus menjadi perhatian bagi institusi yang bernama sekolah, karena apabila disikapi dengan cuek, tidak tertutup kemungkinan yang kecil menjadi besar dan menjelma menjadi bola salju liar yang akan terus menggelinding sehingga jumlah peserta didik yang membolos sekolah akan terus meningkat. Menurut Kun Maryati dan Juju Suryawati menjelaskan bahwa perilaku membolos merupakan salah satu bentuk dari penyimpangan perilaku, penyimpangan itu terjadi karena adanya proses labeling (pemberian julukan, cap atau merk yang dianggap tidak sesuai dengan norma dan nilai sosial) yang diterima seseorang yang membuatnya melakukan penyimpangan(Maryati \& Suryawati, 2010).

Banyak peserta didik yang sering membolos bukan hanya di sekolah-sekolah tertentu saja tetapi banyak sekolah mengalami hal yang sama. Hal ini disebabkan oleh faktor-faktor internal dan eksternal dari anak itu sendiri. Faktor eksternal yang kadang kala menjadikan alasan membolos adalah mata pelajaran yang tidak diminati atau tidak disenangi. Tentu saja 38 
sistem pendidikan yang ketat tanpa diimbangi dengan pola pengajaran yang sifatnya "menyejukkan" membuat anak tidak betah lagi di sekolah. Perilaku membolos ini disebabkan oleh beberapa faktor, yaitu:

1. Faktor pribadi, setiap anak mempunyai kepribadian khusus. Kepribadian ini bisa menjadi sumber munculnya perilaku menyimpang.

2. Faktor keluarga, keluarga merupakan faktor unit sosial paling kecil dalam masyarakat yang peranannya besar sekali terhadap perkembangan sosial, terlebih awal-awal perkembangan yang menjadi landasan perkembangan kepribadian selanjutnya.

3. Faktor lingkungan masyarakat, pada lingkungan masyarakat inilah remaja dihadapkan berbagai bentuk kenyataan yang ada dalam kehidupan masyarakat yang berbeda-beda, akibatnya remaja terpengaruh dengan adanya yang terjadi dalam masyarakat yang mana kurang landasan agamanya, dan masyarakat yang acuh terhadap lingkungan yang ada di sekitarnya.

4. Faktor lingkungan sekolah, bisa menyebabkan timbulnya kenakalan remaja, yang mana penyebab erjadinya kenakalan remaja di picu dari adanya pengaruh temantemannya(Maryati \& Suryawati, 2010).

Perilaku membolos peserta didik yang terjadi di Sekolah Menengah Atas (SMA) Pangudi Luhur Bandar Lampung merupakan fenomena yang perlu penanganan tersendiri oleh pihak sekolah. Menurut hasil wawancara dengan guru bimbingan konseling pada saat survey pra penelitian pada tanggal 22 Agustus 2016, guru bimbingan konseling mengatakan bahwa "ada berbagai macam kenakalan peserta didik di sekolah ini, namun pada umunya kenakalan yang sering terjadi yaitu kurangnya disiplin atau melanggar tata tertib sekolah seperti: perilaku membolos, tidak berkata jujur dan kurang menghargai guru saat guru menerangkan dan layanan konseling individu sudah dilaksanakan tetapi perilaku membolos tetap terjadi”.

Sedangkan alasan dari hasil wawancara yang dikemukakan oleh peserta didik yang pernah melakukan pelanggaran membolos salah satunya "karena diajak teman, pada awalnya saya tidak berniat untuk membolos, namun pada saat jam pelajaran yang memang tidak saya sukai, gurunya suka marah-marah, dan sering memberikan hukuman jika terlambat masuk kelas, sehingga saya tidak masuk pada jam pelajaran itu dan pergi kerumah teman untuk menghindari jam pelajaran itu, tapi akhirnya saya tidak kembali lagi ke sekolah sampai jam pulang sekolah". Permasalahan di atas seharusnya tidak terjadi karena salah satu tugas perkembangan peserta didik adalah belajar dan mampu mengaktualisasikan diri seoptimal mungkin. Jika dalam melaksanakan tugas perkembangan mengalami berbagai hambatan maka akan menghambat tugas perkembangan selanjutnya, oleh karena itu permasalahan tersebut harus kita tangani, pecahkan dan selesaikan.

Melalui penggunaan konseling individual mengambil asumsi sifat dasar perilaku manusia yang cendrung berubah, artinya kegiatan konseling dilakukan tidak hanya satu kali melainkan secara terus menerus oleh konselor. Dengan menerapkan layanan konseling individual konselor berupaya membantu peserta didik untuk mengentaskan masalah dan memperbaiki perilaku menyimpang, sehingga adanya perubahan pada peserta didik dari perilaku yang kurang baik menjadi perilaku yang lebih baik terutama di lingkungan sekolah. Berdasarkan uraian di atas peneliti memiliki tujuan yang ingin dicapai dalam penelitian ini adalah untuk mengetahui penggunaan konseling individual dalam membantu mengatasi perilaku membolos peserta didik kelas XI Sekolah Menengah Atas (SMA) Pangudi Luhur Bandar Lampung. 


\section{Metode Penelitian}

Metode yang digunakan dalam penelitian ini adalah menggunakan pendekatan kualitatif bersifat deskriptif, yaitu metodedalam meneliti suatu objek yang bertujuan membuat deskripsi, gambaran atau lukisan secara sistematis dan objektif, mengenai fakta-fakta, sifatsifat, ciri-ciri serta hubungan diantara unsur-unsur yang ada atau fenomena tertentu. Studi kasus sendiri pada dasarnya merupakan metode untuk menyelidiki atau mempelajari suatu kejadian mengenai perorangan (individu) yang dipandang mengalami kasus.

Populasi dalam penelitian ini adalah peserta didik kelas XI dengan jumlah keseluruhan 28 peserta didik yang terbagi menjadi 2 kelas, 1 kepala sekolah, 1 orang waka kesiswaan, dan 1 orang guru bimbingan dan konseling, yaitu guru yang mempunyai kewenangan untuk melakukan penanganan suatu masalah secara profesional dalam melaksanakan bimbingan dan konseling di SMA Pangudi Luhur Bandar Lampung. Pengambilan sampel dalam penelitian dilakukan dengan menggunakan teknik purposive sampling, yaitu teknik penentuan sampel dengan pertimbangan tertentu.10 Purposive sampling ini dilakukan dengan mengambil orangorang yang terpilih oleh peneliti menurut ciri-cirispesifik yang dimiliki oleh sampel itu, yaitu 7 orang peserta didik kelas XI, dan 1 orang guru bimbingan dan konseling yang melaksanakan layanan bimbingan dan konseling, dan sehingga jumlah sampel dalam penelitian ini yaitu berjumlah 8 orang.

Pengumpulan data-data di lapangan yang diperlukan dalam penelitian ini digunakan beberapa metode, yaitu Interview, Observasi, dan Dokumentasi. Pengolahan data melalui tiga tahap yaitu Reduksi dan kategorisasi data, Display data, Penarikan kesimpulan. Dalam mengolah dan menganlisa data yang telah diperoleh dari lapangan tersebut, penulis menggunakan analisa kualitatif (non statistik) karena data yang diperoleh merupakan data deskriptif. uji kredibilitas data yaitu dengan menggunakan trianggulasi sumber, yaitu dengan cara mengecek data yang diperoleh dari beberapa sumber (wawancara, observasi dan dokumentasi)(Sugiyono, 2011).

\section{Hasil dan Pembahasan}

Prasarana program layanan bimbingan dan konseling Sekolah Menengah Atas

(SMA) Pangudi Luhur Bandar Lampung antara lain:

1. Perlengkapan Administrasi

a. Buku pembinaan

b. Buku catatan pelaksanaan konseling individual

c. Data kebutuhan dan permasalahan konseli

d. Daftar kehadiran peserta didik

e. Surat panggilan orang tua

f. Surat izin masuk dan keluar sekolah

g. Angket jurusan

h. Buku penyelesaian kasus, dll.

2. Fasilitas permanen

a. Ruang bimbingan konseling

b. Meja kursi bimbingan konseling

c. Almari penyimpanan data-data

Dalam pelaksanaan layanan bimbingan dan konseling, tidak hanya guru BK saja yang berperan aktif/bekerja, tetapi juga melibatkan pihak-pihak yang terkait nnya, seperti: wali kelas, pembina osis, guru mata pelajaran, orang tua siswa dan juga penjaga sekolah. Karena masalah peserta didik yang sangat banyak dan tidak mungkin ditangani oleh guru BK sendiri tanpa bantuan oleh pihak lain. Dapat dipahami dalam struktur organisasi pelayanan bimbingan dan konseling di Sekolah Menengah Atas (SMA) Pangudi Luhur Bandar Lampung yang peneliti amati bekerjasama sesuai dengan organisasi yang telah terstruktur. Pemberian layanan 
bimbingan dan konseling baik bidang pribadi, sosial, karir dan belajar sudah dilakukan dengan baik, akan tetapi terdapat kesenjangan yang terjadi adalah penanganan yang diberikan kepada peserta didik adalah peserta didik yang mendapatkan masalah-masalah yang cendrung masalah negatif, salah satu contoh wali kelas melaporkan peserta didik yang tidak masuk sekolah sudah lebih dari tiga kali. Contoh lain guru mata pelajaran yang melaporkan peserta didik kepada guru BK bagi peserta didik yang membolos dijam pelajarannya.

Di Sekolah Menengah Atas (SMA) Pangudi Luhur Bandar Lampung, peserta didik yang memiliki masalah menjadi perhatian dalam lembaga bimbingan dan konseling di sekolah baik guru mata pelajaran, wali kelas, kepala sekolah, serta pihak yang diikutsertakan peranannya dalam mengatasi masalah peserta didik di Sekolah Menengah Atas (SMA) Pangudi Luhur Bandar Lampung Pelaksanaan layanan konseling individual terhadap berbagai permasalahan peserta didik, pelaksanaan layanan konseling individual berperan maksimal atau belum merupakan suatu tugas yang harus diemban oleh pihak sekolah terutama oleh guru BK. Untuk mewujudkan output yang berkualitas tentunya harus diusahakan salah satu caranya melalui pelaksanaan layanan konseling individual yang secara keseluruhan yang optimal dari guru bimbingan konseling untuk mengentaskan permasalahan peserta didiknya.

Di Sekolah Menengah Atas (SMA) Pangudi Luhur Bandar Lampung pada dasarnya pelaksanaan layanan bimbingan dan konseling telah dilaksanakan dengan baik. Layananlayanan telah diberikan secara maksimal kepada peserta didik baik itu layanan bimbingan kelompok, bimbingan klasikal maupun konseling individual. Di Sekolah Menengah Atas (SMA) Pangudi Luhur Bandar Lampung pelaksanaan layanan konseling individual dilaksanakan di luar jam pelajaran karena tidak ada jam khusus untuk guru BK. Pelaksanaan layanan konseling individual dilaksanakan di ruang BK dimulai dari tahap pembukaan, tahap penjelasan dan pengutaraan masalah, tahap kegiatan atau tahap pengakhiran, meskipun tidak semua tahap konseling dilaksanakan secara maksimal. Pelaksanaan layanan konseling individual terjadi kebanyakan didasari atas inisiatif guru BK yaitu dengan cara memanggil peserta didik. Pelaksanaan konseling individual dilakukan dengan cara memanggil peserta didik, dilakukan dengan lebih dahulu menganalisis yang sangat mendalam dengan bekerja sama dengan pihakpihak yang diikutsertakan perlunya peserta didik yang bersangkutan dipanggil.Mengenai teknik atau cara melaksanakan konseling individual pada peserta didik, guru bimbingan dan konseling yang harus selalu aktif dan tegas kepada peserta didik sesuai dengan asas yang berlaku agar peserta didik mau jujur serta mengungkapkan permasalahan kepada guru bimbingan dan konseling.

Untuk dapat memberikan layanan konseling individual dengan efektif dan efisien, guru BK harus memahami peserta didik secara utuh dan memahami pula kondisi lingkungannya sepenuhnya. Pemahaman tersebut diperoleh dari sumber data, baik data pribadi maupun data lingkungan. Data pribadi peserta didik adalah berupa data perorangan, dari data pribadi dapat diperoleh pemahaman tentang keunikan pribadi masing-masing peserta didik. Salah satu contoh masalah pribadi yang ada di Sekolah Menengah Atas (SMA) Pangudi Luhur Bandar Lampung yaitu peserta didik yang membolos dijam pelajaran tertentu maka guru mata pelajaran tersebut melaporkan peserta didik tersebut ke guru bimbingan konseling (BK), selanjutnya guru BK memanggil peserta didik tersebut dan menyelesaikan permasalahan peserta didik tersebut. Menurut hasil observasi yang dilakukan oleh penulis, fakta dilapangan dan wawancara terhadap guru BK di Sekolah Menengah Atas (SMA) Pangudi Luhur Bandar Lampung, kurangnya kesadaran peserta didik akan pentingnya mengikuti layanan konseling individual bisa dikatakan rendah karena layanan konseling individual di sekolah tersebut belumlah berjalan dengan maksimal. Kurangnya kesadaran peserta didik mengikuti layanan konseling individual diantaranya dapat kita lihat dari segi sarana dan prasarana, tidak adanya 
ruangan khusus untuk pelaksanaan konseling individual, dapat diketahui bahwasannya layanan konseling individual dilaksanakan di ruangan terbuka yaitu diruangan bimbingan konseling dimana terkadang proses konseling individual tidak dilaksanakan face to face.

Dampak dari tidak adanya ruangan khusus untuk layanan konseling individual yaitu semua orang seperti dewan guru bahkan peserta didik yang lain bisa melihat proses konseling yang dilaksanakan. Oleh karena itu dapat menyebabkan asas yang sangat mendasar yaitu asas kerahasiaan yang dianut layanan konseling individual tidak terjamin, dan tidak mungkin peserta didikpun menjadi ragu untuk mengungkapkan persoalan/masalah yang sedang dihadapinya, kemudian kurangnya sosialisasi terhadap peserta didik guna mengungkapkan masalahnya kepada guru bimbingan konseling melalui pelaksanaan layanan konseling individual, hal ini dapat dilihat dari minimnya peserta didik yang mau datang ke guru BK berdasarkan inisiatif sendiri. Salah satu penyebabnya karena peserta didik ragu dan takut masalahnya akan diketahui oleh orang lain, seperti yang diungkapkan salah satu peserta didik saat penulis melakukan wawancara penelitian dilapangan.

Pengumpulan data-data yang bersifat kepustakaan dan data lapangan yang berupa hasil penelitian observasi, interview, maupun dokumentasi, yang kemudian dituangkan dalam menyusun bab-bab terdahulu, maka sebagai langkah selanjutnya akan menganalisis data temuan yang ada dan memodifikasi teori yang ada dan kemudian membangun teori yang baru serta menjelaskan tentang implikasiimplikasi dari hasil penelitian ini. Sebagaimana diterangkan dalam teknik analisis data dalam penelitian, peneliti menggunakan analisis kualitatif deskriptif (pemaparan) dan data yang peneliti peroleh baik melalui observasi, interview dan dokumentasi dari pihak-pihak yang mengetahui tentang data yang peneliti butuhkan. Adapun data yang akan dipaparkan dan di analisa oleh peneliti sesuai dengan rumusan penelitian di atas. Untuk lebih jelasnya, maka peneliti akan mencoba untuk membahasnya.

Berdasarkan hasil penelusuran masing-masing aspek secara keseluruhan kondisi layanan bimbingan dan konseling di Sekolah Menengah Atas (SMA) Pangudi Luhur Bandar Lampung sebelumnya masih terdapat beberapa kekurangan, hal itu terlihat dari belum adanya fasilitas pendukung pelaksanaan jasa layanan bimbingan dan konseling yaitu ruang bimbingan konseling secara khusus, sehingga layanan konseling individual dilakukan diruangan terbuka yaitu diruangan bimbingan konseling dimana terkadang proses konseling individual tidak dilaksanakan face to face.

Pelaksanaan layanan konseling individual dilaksanakan di luar jam pelajaran karena tidak ada jam khusus untuk guru BK, dimulai dari tahap pembukaan, tahap penjelasan dan pengutaraan masalah, tahap kegiatan atau tahap pengakhiran, meskipun tidak semua tahap konseling dilaksanakan secara maksimal, serta masih adanya pelanggaran-pelanggaran yang dilakukan oleh peserta didik, khususnya berkenaan dengan tata tertib sekolah.

Memberikan layanan bimbingan kepada peserta didik agar memiliki kemampuan dan keahlian dalam memecahkan masalah sekaligus mencari solusi yang terbaik atau memberikan layanan bimbingan kepada peserta didik, membuat strategi dalam menghadapi berbagai masalah merupakan bagian dari pelaksanaan layanan bimbingan dan konseling. Melalui caracara peserta didik akan diajari bagaimana menentukan pilihan, memecahkan masalah, strategi pemecahan masalah, menghadapi dan mencegah berbagai masalah. Guru adalah sosok yang mempunyai peran penting dalam mencegah perilaku menyimpang peserta didik. Ketepatan dalam menerapkan layanan bimbingan dan konseling menjadi upaya guru dalam mengatasi perilaku menyimpang peserta didik.

Layanan bimbingan dan konseling hadir dalam ranah pendidikan diharapkan mampu berkontribusi dalam perubahan perilaku peserta didik ke arah yang lebih baik lagi. Layanan bimbingan dan konseling berpengaruh dengan pencegahan perilaku menyimpang peserta didik, meskipun secara genetis perilaku menyimpang ini dapat dikatakan berasal dari unsur bawaan, 42 
akan tetapi faktor lingkungan, teman, dan sebagainya sangat berpengaruh terhadap perilaku peserta didik. Layanan bimbingan dan konseling memberikan layanan-layanan yang sesuai dengan setiap permasalahan yang dihadapi peserta didik untuk mendapatkan penyelesaian dan pada akhirnya penyelesaian itu memberikan peluang kepada peserta didik untuk merubah tingkah lakunya terwujud dalam pemebentukan karakter atau watak khas yang ada pada individu peserta didik.

Layanan bimbingan dan konseling memiliki fungsi perbaikan yaitu fungsi layanan bimbingan dan konseling yang akan menghasilkan terpecahnya atau teratasinya berbagai permasalahan yang dialami peserta didik. Hal ini juga sama dengan mencegah perilaku menyimpang yang juga memiliki fungsi perbaikan yaitu memperbaiki perilaku peserta didik yang pada akhirnya mewujudkan emosional yang baik dan berpotensi sebagai peserta didik yang bermartabat dan mampu menerapkan emosional yang positif, serta berperilaku yang sesuai dengan norma-norma yang ada di masyarakat.

Dalam pelaksanaannya, layanan konseling individual dalam membantu mengatasi perilaku membolos peserta didik kelas XI di Sekolah Menengah Atas (SMA) Pangudi Luhur Bandar Lampung dilakukan melalui beberapa tahap, yaitu tahap pembukaan, tahap penjelasan dan pengutaraan masalah, tahap kegiatan atau tahap pengakhiran. Kelima tahap tersebut memiliki keterkaitan antara tahap yang lainnya, dan kesuksesan tahapan sangat menentukan penyelesaian masalah dalam tahap-tahap berikutnya.

Berdasarkan hasil analisis dan pemahaman penulis tersebut di atas, maka dapat disimpulkan bahwa penggunaan layanan konseling individual dalam membantu mengatasi perilaku membolos peserta didik kelas XI di Sekolah Menengah Atas (SMA) Pangudi Luhur Bandar Lampung dilaksanakan melalui beberapa tahapan, yaitu tahap pembukaan, tahap penjelasan dan pengutaraan masalah, tahap kegiatan atau tahap pengakhiran. Upaya yang dilakukan oleh guru bimbingan dan konseling Sekolah Menengah Atas (SMA) Pangudi Luhur Bandar Lampung tersebut dilakukan dengan bekerjasama dengan orang tua peserta didik.

\section{Simpulan dan Saran}

Kesimpulan yang dapat diambil yaitu Guru bimbingan konseling melakukan konseling individual dengan menggunakan tahapan-tahapan diantaranya pembukaan, penjelasan masalah, penggalian latar belakang masalah, penyelesaian masalah dan penutup. Pelaksanaan konseling individual dilakukan dengan cara memanggil peserta didik, dilakukan dengan lebih dahulu menganalisis yang sangat mendalam dengan bekerja sama dengan pihak-pihak yangdiikutsertakan perlunya peserta didik yang bersangkutan dipanggil. selain itu layanan konseling individual hanya ditujukan sebagian besar pada peserta didik bermasalah yang cendrung perilaku negatif di sekolah salah satunya perilaku membolos pesertadidik. Hasil layanan konseling individual di Sekolah Menengah Atas (SMA) Pangudi Luhur Bandar Lampung hasilnya masih ada peserta didik yang membolos saat jam pelajaran berlangsung maupun membolos sekolah tanpa adanya keterangan atau tanpa ada kejelasan.

Saran pada setelah melakukan penelitian yaitu, Untuk memotivasi peserta didik melakukan konseling individual, diharapkan layanan konseling individual pada pelaksanaannya dapat berjalan dengan maksimal dan seefektif mungkin, diterapkan pendekatan/teknik dengan teori yang ada dan sesuai dengan permasalahan peserta didik akan sangat membantu mengentaskanpermasalahan peserta didik di sekolah, perlu adanya ruangan dan jam khusus layanan konseling individual guna mendukung proses konseling terhadap peserta didik. 


\section{Daftar Pustaka}

Abu, A., \& Uhbaiti, N. (2001). Ilmu Pendidikan. Jakarta: PT. Rineka Cipta.

Maryati, K., \& Suryawati, J. (2010). Sosiologi 1 B For Senior High School Grade X Semester 2. Jakarta: Gelora Aksara Pratama.

Richard-Jones, N. (2011). Theory and Practice Of Conceling and Teraphy, . (T. Helly \& T. dan P. K. dan T. Prajitno Soetjipjo, Eds.). Yogyakarta, , hlm. .: Pustaka Pelajar.

S. Willis, S. (2013). Konseling Individual Teori dan Praktek. Bandung: Alfabeta.

Sarwono, S. W. (2010). Psikologi Remaja. Jakarta: Rajawali Pers.

Sugiyono. (2011). Statistik Untuk Penelitian.pdf.

Sukardi, D. K. (2000). Pengantar Pelaksanaan Program Bimbingan dan Konseling di Sekolah, Jakarta: PT Rineka Cipta.

Thalib, S. B. (2010). Psikologi Pendidikan Berbasis Analisis Empiris Edukatif. Jakarta: Kencana. 